\title{
KAJIAN PASAL 1338 KITAB UNDANG-UNDANG HUKUM PERDATA TENTANG \\ AKIBAT SUATU PERJANJIAN DALAM SEWA MENYEWA LAHAN (GARAM \\ (STUDI KASUS DESA KARANGANYAR)
}

MOH. ZAINUDIN

Fakultas Hukum, Universitas Wiraraja Sumenep

zainuddin@gmail.com

\begin{abstract}
ABSTRAK
Perjanjian adalah suatu persetujuan yang terjadi antara dua orang atau lebih yang mengikatkan dirinya terhadap orang lain. Perjanjian hendaknya menyebutkan bahwa kedua belah pihak harus saling mengikat Apabila dalam pembuatan perjanjian, salah satu syarat sahnya perjanjian tidak terpenuhi maka perjanjian tersebut belum bisa dikatakan sah Asas kebebasan berkontrak bukan berarti menghalalkan bagi para pihak untuk mengingkari kontrak perjanjian yang telah terlebih dahulu terjadi Unsur yang penting dalam perjanjian adalah adanya persetujuan (kesepakatan) antara para pihak. Sifat persetujuan dalam suatu perjanjian di sini harus tetap, bukan sekedar berunding Sering terjadi permasalahan yang awalnya bermula dari perjanjian yang pada kenyataannya salah satu pihak tidak memenuhi prestasi sesuai dengan apa yang telah diperjanjikan.
\end{abstract}

Kata Kunci : Kajian Pasal Hukum Perdata, Sewa Menyewa Lahan.

\section{A. PENDAHULUAN}

Perjanjian adalah suatu persetujuan yang terjadi antara dua orang atau lebih yang mengikatkan dirinya terhadap orang lain. Perjanjian yang dimaksud diatas adalah pengertian perjanjian yang masih dalam arti yang masih sangat luas, karena pengertian tersebut hanya mengenai perjanjian sepihak dan tidak menyangkut mengikatnya kedua belah pihak.

Apabila dalam pembuatan perjanjian, salah satu syarat sahnya perjanjian tidak terpenuhi maka perjanjian tersebut belum bisa dikatakan sah, syarat-syarat perjanjian juga berlaku dalam pembuatan suatu perjanjian sewa menyewa. Asas kebebasan berkontrak bukan berarti menghalalkan bagi para pihak untuk mengingkari kontrak perjanjian yang telah terlebih dahulu terjadi,

Sering terjadi permasalahan yang awalnya bermula dari perjanjian yang pada kenyataannya salah satu pihak tidak memenuhi prestasi sesuai dengan apa yang telah diperjanjikan, Bentuk perjanjian mempunyai kekuatan mengikat dan kekuatan bukti. Bentuk tertentu biasanya berupa akta. Perjanjian itu dapat dibuat lisan, artinya dengan kata-kata yang jelas.

Dengan permasalahan yang penulis akan jelajahi, maka penulisan ini akan difokuskan pada pembahasan tentang “Kajian Pasal 1338 Kitab UndangUndang Hukum Perdata Tentang Akibat Suatu Perjanjian Dalam Sewa Menyewa 
Lahan (Garam (Studi Kasus Desa Karanganyar).”

Adapaun yang menjadi rumusan masalah dalam tulisan ini adalah Langkah apa yang dilakukan dalam perjanjian menurut Pasal 1338 jika lahan garam dikuasai pihak lain?

Tujuan dalam penelitian ini, yaitu : Untuk mengkaji dan menganalisis Langkah apa yang dilakukan dalam perjanjian menurut dari Pasal 1338 jika lahan garam dikuasai pihak lain. dan menganalisis Pertanggung jawaban pemilik lahan garam yang dikuasai pihak lain.

Metode pendekatan masalah yang digunakan oleh peneliti dengan cara menggunakan yuridis normatif dimana Kajian Pasal 1338 Kitab Undang-Undang Hukum Perdata Tentang Akibat Suatu Perjanjian Dalam Sewa Menyewa Lahan (Garam (Studi Kasus Desa Karanganyar).

\section{B. PEMBAHASAN}

Perjanjian yang sah artinya perjanjian yang memenuhi syarat yang telah ditentukan oleh undang- undang, sehingga ia diakui oleh hukum (legally concluded contract) maka dari itu perlu kiranya langkah-langkah yang harus diterapkan dalam suatu perjanjian sesuai pasal 1338 Kitan Undang-Undang Hukum Perdata dimana yaitu

1. Azas kebebasan berkontrak tercermin dalam Pasal 1338 KUH Perdata yang menyebutkan bahwa “ Semua perjanjian yang dibuat secara sah berlaku sebagai undang-undang bagi yang membuatnya". Implementasi azas ini dalam perjanjian leasing harus didukung oleh azas-azas yang lain dalam perjanjian.

2. Azas iktikad baik adalah yang menekankan pada norma-norma kepatutan dan kesusilaan. Jika azas tersebut diterapkan, maka kesewenang-wenangan terutama dari pihak lessor yang dengan mudah dapat memaksa pihak lesse yang melanggar kewajiban untuk melaksanakan kewajibannya dapat diminimalisir dengan mengkaji dan mempertimbangkan alasan--alasan yang mendasari terjadinya pelanggaran terhadap suatu perjanjian yang telah disepakati.

Latar belakang lahirnya asas kebebasan berkontrak adalah adanya paham individualisme yang menurut paham individualisme, setiap orang bebas untuk memperoleh apa saja yang dikehendakinya. Dalam hukum kontrak asas ini diwujudkan dalam "kebebasan berkontrak". Teori leisbet fair ini menganggap bahwa the invisible hand akan menjamin kelangsungan jalannya persaingan bebas. Karena pemerintah sama sekali tidak boleh mengadakan intervensi didalam kehidupan sosial ekonomi masyarakat. 
Pada akhir abad ke-19, akibat desakan paham etis dan sosialis, paham individualisme mulai pudar, terlebih-lebih sejak berakhirnya Perang Dunia II. Paham ini kemudian tidak mencerminkan keadilan. Masyarakat menginginkan pihak yang lemah lebih banyak mendapat perlindungan.

Oleh karena itu, kehendak bebas tidak lagi diberi arti mutlak, akan tetapi diberi arti relatif dikaitkan selalu dengan kepentingan umum. Pengaturan substansi kontrak tidak semata-mata dibiarkan kepada para pihak namun perlu juga diawasi.

Namun seiring dengan berkembangnya paham Welfare State menyebabkan semakin besarnya keikutsertaan negara dalam mengatur dan mengelola berbagai lapangan kehidupan masyarakat. Muncullah berbagai peraturan yang dikeluarkan oleh negara, misalnya tentang perlindungan terhadap buruh yang wajib dimasukkan dalam perjanjian. Gejala ini justru juga mengakibatkan asas kebebasan berkontrak kurang atau bahkan tidak dapat diwujudkan walapun perjanjian tersebut terjadi antar individu.

Asas kebebasan berkontrak juga berkaitan erat dengan isi perjanjian, yaitu kebebasan menentukan "apa" dan dengan "siapa" perjanjian itu diadakan. Dan perjanjian yang dibuat trsebut sesuai dengan pasal 1320 KUH Perdata ini mempunyai kekuatan mengikat. Meninjau masalah "ada" dan "kekuatan mengikat" pada perjanjian baku, maka secara teoretis yuridis perjanjian tersebut (standard contract) tidak memenuhi elemen-elemen yang dikehendaki Pasal 1320 jo 1338 KUH Perdata.

Melihat permasalahan ini terdapat dua paham bahwa apakah perjanjian baku tersbut melanggar asas kebebasan berkontrak atau tidak. Paham pertama secara mutlak memandang bahwa perjanjian baku bukanlah suatu perjanjian, sebab kedudukan pengusaha di dalam perjanjian adalah seakan-akan sebagai pembentuk undang-undang swasta. Syarat-syarat yang ditentukan pengusaha di dalam perjanjian itu adalah undang-undang bukan perjanjian. Paham kedua cenderung mengemukakan pendapat bahwa perjanjian baku dapat diterima sebagai perjanjian, berdasarkan fiksi adanya kemauan dan kepercayaan yang membangkitkan kepercayaan bahwa para pihak mengikatkan diri pada perjanjian itu. Dengan asumsi bahwa jika debitur menerima dokumen suatu perjanjian itu, berarti ia secara sukarela setuju pada isi perjanjian tersebut.

Penulis sendiri dalam hal ini tidak memihak pada salah satu dari kedua paham tersebut. Di satu sisi penulis lebih melihat bahwa perjanjian baku secara teoretis yuridis bertentangan dengan asas kebebasan berkontrak dengan tidak 
terpenuhinya ketentuan undang-undang yang mengatur. Namun di sisi lain kitapun tak dapat menutup mata akan perkembangan yang terjadi mengenai hal ini, dimana dalam kenyataannya, kebutuhan masyarakat cenderung berjalan dalam arah yang berlawanan dengan keinginan hukum bahkan telah menjadi kebiasaan yang berlaku di lingkungan masyarakat dan lalu lintas perdagangan, dengan mempertimbangkan faktor efesiensi baik dari segi biaya, tenaga dan waktu, dan lainnya.

Secara umum dapat disimpulkan bahwa yang dimaksud dengan perjanjian adalah suatu perhubungan hukum antara dua orang atau dua pihak, berdasarkan mana pihak yang satu berhak menuntut sesuatu hal dari pihak yang lain, dan pihak yang lain berkewajiban untuk memenuhi tuntutan itu perjanjian seharusnya dilakukan dengan iktikad baik bagi mereka yang melakukannya, dalam suatu perjanjian yang dalam hal ini jelas menimbulkan hak dan kewajiban, maka ditentuklah perundang-undangan yang mengatur perjanjian yang perlu dipahami pihak yang melakukan perjanjian agar kemungkinan pelanggaran dalam perjanjian yang dapat dihindari dan melindungi kedua belah pihak yang melakukannya.

Pada Pasal 1338 KUHPerdata "Semua perjanjian yang dibuat secara sah berlaku sebagai undang-undang bagi mereka yang membuatnya". Artinya bahwa semua ketentuan dalam perjanjian yang telah disepakati para pihak mengikat dan wahib dilaksankan oleh para pihak yang membuatnya. Apabila salah satu pihak tidak melaksanakan perjanjian maka pihak yang dirugikan dapat menuntut ganti rugi kepada pihak yang tidak melaksanakan tadi Asas ini dimaksudkan bahwa suatu perjanjian hanya berlaku bagi para pihak yang membuatnya.

Akibat Hukum Perjanjian yang Sah dalam Pasal 1338 ayat (1) KUH Perdata, yang menyatakan bahwa semua kontrak (Perjanjian) yang dibuat secara sah berlaku sebagai Undang-undang bagi mereka yang membuatnya, perjanjian tidak dapat ditarik kembali secara sepihak apabila keduabelah pihak tidak melanggar perjanjian yang telah dibuatnya dan pelaksanaan perjanjian harus dengan itikad baik.

Ganti kerugian adalah suatu kewajiban yang dibebankan kepada orang yang telah bertindak melawan hukum dan menimbulkan kerugian pada orang lain karena kesalahannya tersebut. Pada masa ini telah dikenal adanya "personal reparation", yaitu semacam pembayaran ganti rugi yang akan dilakukan oleh seseorang yang telah melakukan tindak pidana atau keluarganya terhadap korban yang telah dirugikan sebagai akibat tindak pidana tersebut. 
Pada suatu perjanjian terdapat para pihak dimana masing-masing pihak mempunyai kewajiban yang timbul dari perjanjian yang telah disepakati bersama. Hak dan kewajiban itu harus dilaksanakan secara sukarela. Apabila hak tersebut tidak dilaksanakan atau dengan kata lain tidak memenuhi apa yang dijanjikan maka ia dikatakan melakukan wanprestasi (ingkar janji).

Berdasarkan pendapat di atas, bila dalam suatu perjanjian telah ditentukan bahwa objek dari suatu perjanjian akan diserahkan pada waktu yang telah ditentukan, namun pada waktu tersebut objeknya tidak diserahkan, sedangkan waktu telah tiba untuk diserahkan, dalam hal ini dikatakan telah terjadi wanprestasi atau ingkar janji. Selain itu, munculnya sengketa ataupun perselisihan dalam suatu perjanjian dapat pula disebabkan oleh adanya perbuatan melawan hukum. Hal ini diketahui apabila ditelaah dari ketentuan hukum atau perbuatan hukum perdata, hubungan hukum antara pemilik modal dengan pemilik tanah dalam perjanjian bangun bagi juga erat kaitannya dengan timbulnya kerugian bagi para pihak apabila terjadi kerugian akibat tindakan salah satu pihak yang dilakukan secara melawan hukum mengingkari ketentuan dalam perjanjian.

Sengketa atau konflik umumnya bersumber dari adanya perbedaan pendapat atau ketidaksesuaian di antara para pihak. Apabila pihak-pihak tidak berhasil menemukan bentuk penyelesaian yang tepat, maka perbedaan pendapat ini dapat berakibat buruk bagi kelangsungan hubungan di antara keduanya. Oleh karena itu, setiap menghadapi perbedaan pendapat (sengketa), para pihak selalu berupaya menemukan cara-cara penyelesaian yang tepat.

Pada awalnya, bentuk-bentuk penyelesaian sengketa yang dipergunakan selalu berorientasi pada bagaimana supaya memperoleh kemenangan (seperti peperangan, perkelahian bahkan lembaga pengadilan). Oleh karena kemenangan yang menjadi tujuan utama, para pihak cenderung berupaya mempergunakan berbagai cara untuk mendapatkannya, sekalipun melalui cara-cara melawan hukum. Akibatnya, apabila salah satu pihak memperoleh kemenangan tidak jarang hubungan diantara pihakpihak yang bersengketa menjadi buruk, bahkan berubah menjadi permusuhan.

Pada masa ini telah dikenal adanya "personal reparation", yaitu semacam pembayaran ganti rugi yang akan dilakukan oleh seseorang yang telah melakukan tindak pidana atau keluarganya terhadap korban yang telah dirugikan sebagai akibat tindak pidana tersebut. Pada masa belum adanya pemerintahan, atau dalam masyarakat yang masih berbentuk suku-suku ini (tribal organization) bentuk-bentuk 
hukuman seperti ganti rugi merupakan sesuatu yang biasa terjadi sehari-hari. Bentuk-bentuk kerugian dapat kita bedakan atas dua bentuk yakni :

a. Kerugian materiil

b. Kerugian immateriil

Undang-undang hanya mengatur penggantian kerugian yang bersifat materiil. Kemungkinan terjadi bahwa kerugian itu menimbulkan kerugian yang immateriil, tidak berwujud, moril, idiil, tidak dapat dinilai dengan uang, tidak ekonomis, yaitu berupa sakitnya badan, penderitaan batin, rasa takut, dan sebagainya.

Maksud dari bentuk Ganti rugi sesuai Pasal 1242 Kitab Undang-Undang Hukum Perdata ada tiga bentuk ganti rugi yaitu sebagai berikut :

a. Biaya

Di dalam Biaya, sebagai segala pengeluaran atau perongkosan yang nyata-nyata sudah dikeluarkan oleh satu pihak. Contoh nya jika seorang sutradara mengadakan suatu perjanjian dengan pemain sandiwara untuk mengadakan suatu pertunjukan dan pemain tersebut tidak datang sehingga pertunjukan terpaksa dibatalkan, maka yang termasuk biaya adalah ongkos cetak iklan, sewa gedung, sewa kursi dan lain-lain.

b. Kerugi

Kerugian dimaksudkan adalah kerugian karena kerusakan barang- barang kepunyaan kreditur yang diakibatkan oleh kelalaian si debitur. Misalnya rumah yang baru diserahkan oleh pemborong ambruk karena salah konstruksinya, hingga merusak perabot rumah.

c. Bunga

Bunga di sini merupakan kerugian yang berupa kehilangan keuntungan yang sudah dibayangkan atau dihitung oleh kreditur. Misalnya, dalam hal jual beli barang, jika barang tersebut sudah mendapat tawaran yang lebih tinggi dari harga pembeliannya.

\section{PENUTUP}

Langkah-langkah yang dilakukan dalam perjanjian pada Pasal 1338 KUHPerdata yaitu dengan Azas kebebasan berkontrak tercermin dalam Pasal 1338 KUH Perdata yang menyebutkan bahwa "Semua perjanjian yang dibuat secara sah berlaku sebagai undangundang bagi yang membuatnya". Implementasi azas ini dalam perjanjian leasing harus didukung oleh azas-azas yang lain dalam perjanjian selain itu dengan Azas iktikad baik adalah yang menekankan pada norma-norma kepatutan dan kesusilaan. Jika azas tersebut diterapkan, maka kesewenangwenangan terutama dari pihak lessor yang dengan mudah dapat memaksa pihak lesse yang melanggar kewajiban untuk melaksanakan kewajibannya dapat diminimalisir dengan mengkaji dan mempertimbangkan alasan-alasan yang 
mendasari terjadinya pelanggaran terhadap suatu perjanjian yang telah disepakati. Apabila salah satu pihak tidak melaksanakan perjanjian maka pihak yang dirugikan dapat menuntut ganti rugi kepada pihak yang tidak melaksanakan tadi, asas ini dimaksudkan bahwa suatu perjanjian hanya berlaku bagi para pihak yang membuatnya.

\section{DAFTAR PUSTAKA}

Abdulkadir Muhammad. Hukum Perdata Indonesia. Bandung: Citra Aditya Bakti. 2011.

Ahmad Ichsan, Hukum Perdata IA, Pembimbing Masa, Jakarta, 2009.

Darda Syahrizal. Kasus-Kasus Hukum Perdata Di Indonesia. Galang Perss:Yogyakarta. 2011.

Peter Mahmud Marzuki. 2010. Penelitian Hukum. Kencana Prenada Media Grop, Jakarta.

Munir Fuady, Hukum Kontrak (Dari Sudut Pandang Hukum Bisnis, Citra Aditya Bakti, Bandung, 2007.

R. Subekti, “Hukum Perjanjian”, Intermasa, Jakarta, 2005.

Pokok-pokok Hukum Perdata, Intermasa: Jakarta, 2005.

Riduan Syahrani, Seluk-beluk dan Azas-azas Hukum Perdata, Bandung:
Alumni. 2002.

Sudikno Mertokoesumo, “Mengenal Hukum”, Liberty, Yogyakarta, 2009.

Titik Triwulan Tutik, Hukum Perdata dalam Sistem Hukum Nasional, (Jakarta: Kencana Prenada Media Grup, 2011.

Widjaja Gunawan \& Muljadi Kartini, Perikatan Yang Lahir dari Perjanjian, Jakarta: Raja Grafindo Persada, 2004.

R. Subekti, R. Tjitrosudiblo, Kitab UndangUndang Hukum Perdata, (Jakarta : Pradnya Paramita. 2001.

KUHAPer Dilengkapi Yurisprodensi. 2006. Mahkamah Agung dan Hoge Raad, PT. Raja Grafindo Persada, Jakarta.

http://ihsan26theblues.wordpress.com/2011/0 6/02/hukum-perjanjian/ diakses hari minggu, Tanggal 20 Maret 2016. 